\title{
Perbaikan Proses Bisnis Logistik Sampah di Kota Cirebon Menggunakan Metode Business Process Improvement (BPI)
}

\author{
Sutandi \\ Program Studi Logistik, Institut Ilmu Sosial dan Manajemen STIAMI \\ sutankindi@gmail.com, sutandi@stiami.ac.id
}

\section{ARTICLE INFO}

\section{Article History}

Received: 29 December 2019

Reviewed: 5 Pebruary 2020

Published: 30 April 2020

Available Online: 30 April

2020

Keywords:

policy, logistics, business process improvement, waste management

\section{ABSTRACT}

One of the main issues in the city of Cirebon is the problem of waste management. The City of Cirebon's Environmental Service is tasked with managing waste from Households and Industries to the Garbage Collection Site (TPS) to the Final Disposal Site (TPA). The business process of transporting waste from TPS to TPA still often experiences obstacles, one of which is the delay in transportation from TPS to TPA because it does not pay attention to the connectivity of waste flow and information flow as a single entity that forms a waste logistics network. The purpose of this study is to propose the design of waste logistics policy through improving the waste logistics business process. The research method applied by using the fishbone diagram and five whys analysis methods sourced from interviews, and field observations in finding the fundamental problems of each business process. The basic problem based on the results of the analysis is the accumulation of waste at the TPS. With the results of observations it will be designed improvements with streamlining tools analysis tools on Business Process Improvement (BPI) in presenting business process recommendations. Based on business process recommendations, then run a simulation to see performance improvements for each business process, with an increase in the performance of garbage delivery trucks from TPS to TPA by $34.31 \%$ so as to reduce the accumulation of waste in TPS.

\section{A. PENDAHULUAN}

\section{Latar Belakang}

Menurut Weske (2012), proses bisnis merupakan kumpulan aktifitas kegiatan yang saling terkait dan terkoordinasi yang mendukung tercapainya tujuan bisnis suatu perusahaan atau organisasi. Kegiatan operasional organisasi dalam pencapaian visi yang telah ditentukan didukung oleh suatu proses bisnis. Proses bisnis yang baik dan benar akan menjamin kegiatan lebih efektif dan efisien.

Salah satu isu utama di Kota Cirebon adalah masalah pengelolaan sampah. Dinas Lingkungan Hidup Kota Cirebon bertugas mengelola sampah dari Rumah Tangga dan Industri ke Tempat Pengumpulan Sampah (TPS) sampai dengan Tempat Pembuangan Akhir (TPA). Proses bisnis pengangkutan sampah dari TPS ke TPA masih sering mengalami kendala, salah satunya adalah keterlambatan pengangkutan dari TPS ke TPA karena belum memperhatikan konektivitas aliran sampah dan aliran informasi sebagai satu kesatuan yang membentuk sebuah jaringan logistik persampahan.

Untuk menentukan akar permasalahan penelitian ini menggunakan metode fishbone diagram dan five whys analysis. Diagram tulang ikan atau fishbone diagram adalah salah satu metode/tool di dalam meningkatkan kualitas dengan mengidentifikasi dan mengorganisasi penyebab-penyebab yang mungkin timbul dari suatu efek spesifik dan kemudian memisahkan akar penyebabnya (Murnawan, 2014). Metode five whys analysis digunakan untuk menggali akar permasalahan dengan cara bertanya "mengapa" sampai menemukan akar permasalahan. Tujuan dari metode five whys analysis akan mengarah pada pemecahan masalah yang ada. (Robert, 2000).

Dalam menganalisis perbaikan proses bisnis suatu organisasi dibutuhkan metode yang tepat dengan menggunakan metode Business Process Improvement (BPI). Suatu organisasi akan memperoleh keuntungan 
yang signifikan dengan perubahan proses bisnis yang lebih baik (Harrington, 1991). Keunggulan metode 12 tools streamlining pada BPI dapat menyederhanakan proses bisnis sehingga lebih efektif dan efisien. Sehingga metode BPI sangat populer digunakan dalam perbaikan proses bisnis (Kusuma, 2015).

Metode simulasi proses bisnis digunakan untuk mengembangkan alur proses bisnis yang lebih baik, mencegah kekurangan dan kelebihan penggunaan sumber daya manusia dan biaya, meminimalisir resiko kegagalan model, mengoptimalkan kinerja sistem pada organisasi, serta untuk menghilangkan resiko (Bizagi, 2018).

Berdasarkan permasalahan diatas, dalam rangka peningkatan kinerja logistik sampah di Kota Cirebon, penulis tertarik melakukan penelitian untuk memperbaiki proses bisnis logistik sampah di Kota Cirebon dengan memodelkan dan diterapkan BPI dalam menganalisa proses bisnis serta memberikan usulan rekomendasi kebijakan dalam peningkatan kinerja proses bisnis logistik sampah untuk pemangku kebijakan yaitu Kepala Dinas Lingkungan Hidup Kota Cirebon.

\section{Tinjauan Pustaka}

\section{Logistik dan Supply Chain Management (SCM)}

Jika dilihat secara keseluruhan SCM memiliki rantai mulai dari supplier sampai pelanggan dengan membahas seluruh aktivitas perusahaan mulai dari level strategis, level tactical, hingga level operasional (Anwar, 2011) dan (Siagian, 2012).

Aktor utama SCM antara lain:

a. Rantai 1: Supplier adalah penyedia bahan baku, bahan mentah, bahan penolong, bahan dagangan, dan sebagainya.

b. Rantai 1-2: Manufacture adalah instalasi mengelola/memproses bahan baku/mentah hingga menjadi bahan jadi.

c. Rantai 1-2- 3: Distributor adalah entitas yang bertugas menyaluran barang dari manufacture ke pelanggan.

d. Rantai1-2-3-4: Retail outlet adalah pedagang besar yang mempunyai fasilitas penyimpanan yang untuk menyimpan barang sebelum disalurkan lagi ke pihak pengecer.

e. Saluran 1-2-3-4-5: Customers adalah pada pengecer/retailers menawarkan barangnya langsung kepada para pelanggan.

\section{Manajemen Logistik}

Manajemen logistik adalah proses pengelolaan strategis dalam pemindahan dan penyimpanan barang, suku cadang, barang jadi dari supplier kepada pelanggan (Bowersox, DJ, 2006 dalam Rizky,2012),.

Pengelolaan persampahan merupakan bagian dari manajemen rantai pasok dan logistik green. Beberapa penelitian yang mengkaji permasalahan ini antara lain Huang et al. dan Zhu et al. yaitu kajian praktik rantai pasok green di Cina, sedangkan Lee et al. membahas sector industry elektronik di Korea. Selanjutnya Zhu et al.menganalisis praktik rantai pasok green terhadap power industries, chemical/petroleum, electrical/electronic dan automobile terhadap kinerja perusahaan di Amerika Serikat. Eltayeb et al. membahas prakarsa rantai pasok hijau di perusahaan-perusahaan Malaysia.

Disamping itu, strategi green juga diperlukan peran dari pemerintah. Sheu membahas perjanjian kerjasama dalam hal negosiasi reverse logistics dibawah pengawasan pemerintah. Andiç et al. Menyarankan peran aktif pemerintah dalam meningkatkan praktik green supply chain management. Chen et al. Memberikan beberapa metode strategi bisnis dalam rantai pasok green. Berbagai penelitian rantai pasok green ini menunjukan berbagai masalah pada level operasional, taktikal dan strategis

\section{Pengelolaan Persampahan}

Undang-Undang Nomor 18 Tahun 2008 tetang Pengelolaan Sampah, Pengelolaan sampah adalah kegiatan yang sistematis, menyeluruh, dan berkesinambungan yang meliputi pengurangan dan penanganan sampah. 


\section{Proses Bisnis}

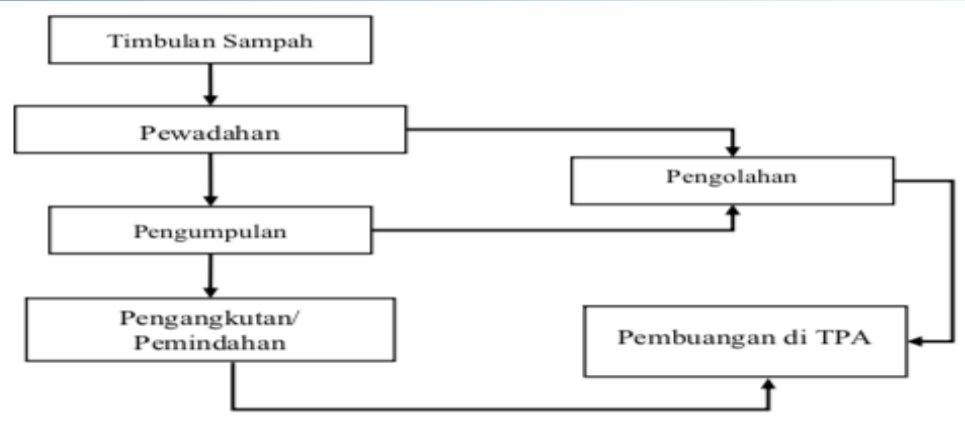

Gambar 1 Skema Teknis Operasional Pengelolaan Sampah

Proses bisnis adalah serangkaian kegiatan koordinasi di sebuah organisasi dan lingkungan teknis yang bersama-sama mewujudkan tujuan bisnis organisasi (Weske, 2012). Menurut H. James Harrington (1991), proses bisnis adalah semua proses jasa dan proses yang mendukung proses produksi. Proses bisnis terdiri dari sekumpulan tugas yang terkait logis yang menggunakan sumber daya organisasi untuk memberi hasil yang mendukung tujuan organisasi. Sedangkan proses produksi adalah semua proses yang mengalami kontak fisik dengan perangkat keras dan perangkat lunak yang akan dikirim ke pelanggan eksternal, sampai ke titik di mana produk di pak. Proses produksi tidak meliputi proses pengiriman dan distribusi.

\section{Value Chain}

Manajemen rantai nilai (value chain management) pertama kali dikemukakan oleh Keith Oliver dan Weber pada tahun 1982 yang pertama kali dipraktikkan tahun 1985 pada industri tekstil dan pakaian (Perdana, 2009). Menurut Chopra \& Meindl (2004) dalam manajemen rantai nilai, terdapat empat penggerak yaitu persediaan, transportasi, fasilitas, dan informasi. Informasi menjadi penggerak utama karena informasi sangat mempengaruhi ketiga penggerak lainnya.

Dalam mengidentifikasi proses bisnis menjadi proses bisnis utama dan proses bisnis pendukung digunakan value chain analysis. Aktivitas utama antara lain produksi, hubungan pelanggan, dan penjualan produk. Aktivitas utama dapat dibagi antara lain: inbound logistic, operations, outbound logistic, marketting $\&$ sales, service. (Porter, 1998).

\section{Fishbone Diagram (Cause and Effect Diagram)}

Diagram sebab akibat disebut juga diagram tulang ikan (fishbone diagram) yang digunakan untuk mengidentifikasi dan menganalisis suatu proses atau situasi dan menemukan kemungkinan penyebab suatu persoalan / masalah yang terjadi. Diagram sebab akibat dirancang pertama kali oleh Dr. Kaoru Ishikawa pada tahun 1943, yang juga dikenal dengan sebutan Ishikawa Diagram. (Ishikawa S Seven Basic Tools for Quality Control, 2002)

\section{Business Process Improvement (BPI)}

Bussiness Process Improvement (BPI) didefinisikan oleh H. James Harrington (1991) sebagai berikut "BPI is a systematic methodology developed to help an organization make significant advances in the way its business processes operate".

Harrington menyatakan terdapat 5 tahapan untuk melakukan perbaikan proses bisnis, yaitu :

1. Mengorganisasi perbaikan.

2. Memahami proses.

3. Streamlining.

4. Pengukuran dan pengendalian.

5. Perbaikan berkelanjutan. 


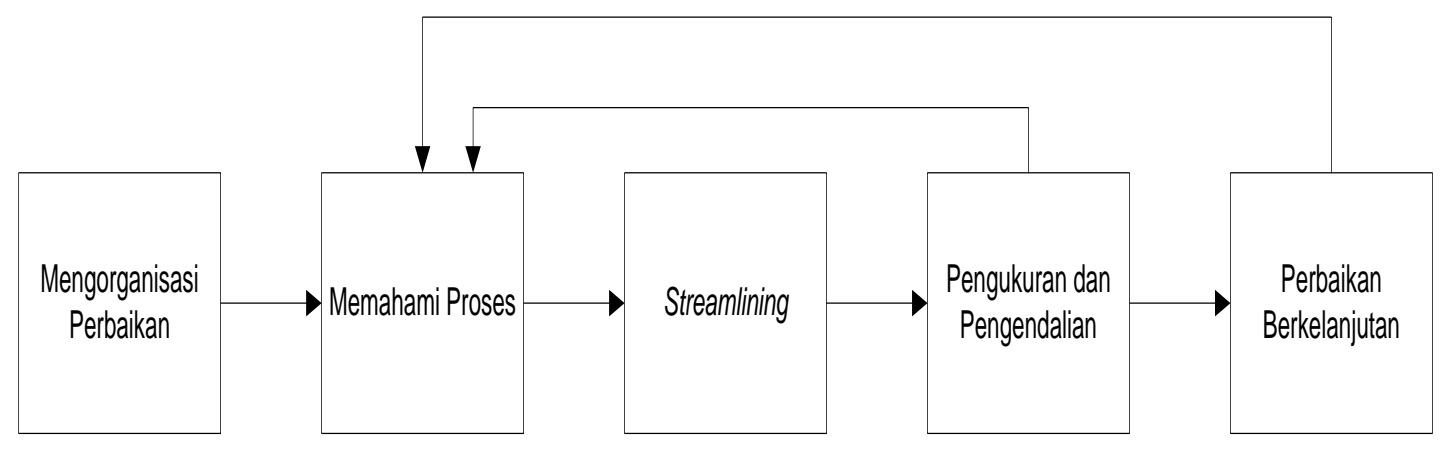

Gambar 2 Model BPI H. James Harrington

\section{Tahap I, Mengorganisasikan Perbaikan}

Langkah pertama yang harus dilakukan untuk memulai kegiatan perbaikan adalah dengan merencanakan dan mengorganisir perbaikan. Langkah ini bertujuan untuk menjamin keberhasilan dengan membangun kepemimpinan, pengertian, dan komitmen dari berbagai elemen yang terlibat dalam perbaikan proses secara langsung atau secara tidak langsung.

\section{Tahap II, Memahami Proses}

Sebelum melakukan perbaikan proses bisnis, Process Improvement Team (PIT) harus dapat memahami proses yang terjadi dengan sangat baik. Semakin baik pemahaman PIT terhadap proses, maka semakin banyak perbaikan yang dapat ditingkatkan. Adapun karakteristik proses bisnis adalah :

a. Flow : Cara-cara mengubah input menjadi output.

b. Effectiveness : Seberapa baiknya harapan pelanggan dapat dipenuhi.

c. Efficiency: Seberapa baik tingkat penggunaan sumber daya untuk menghasilkan output.

d. Cycle time : Waktu yang digunakan untuk mengubah input menjadi output.

e. Cost : Pengeluaran untuk keseluruhan proses.

3. Tahap III, Streamlining

Streamlining adalah langkah yang dilakukan untuk membuang bagian-bagian pekerjaan yang tidak berguna, memberi perhatian secara detail setiap waktu yang akan menyebabkan terjadinya perbaikan kerja dan kualitas. Pada tahap ini terdapat 12 tools streamlining, antara lain: Bureaucray Elimination, Simple Language, Duplication Elimination, Process Cycle-time Reduction, Simplification, Error Proofing, Standardization, Automation and/or Mechanization Upgrading, Big Picture Improvement, dan Value-added Assessment Supplier Partnerships.

\section{Tahap IV, Pengukuran dan Pengendalian}

Sasaran dari pengukuran dan pengendalian adalah untuk mengimplementasikan sebuah sistem untuk mengendalikan proses untuk perbaikan. Pengukuran merupakan hal yang penting dalam proses perbaikan. Disadari bahwa jika kita tidak dapat membuat pengukuran, maka kita tidak akan dapat mengendalikannya.

\section{Tahap V, Perbaikan Berkelanjutan}

Sasaran dari perbaikan berlanjut adalah peningkatan atau perbaikan yang berkesinambungan. Walaupun hasil perbaikan sudah dicapai, bukan berarti sudah selesai, itu baru permulaan untuk mendapatkan perbaikan yang lebih baik lagi. Demikian seterusnya siklus perbaikan berkesinambungan ini.

\section{Business Process Model and Notation (BPMN)}

Business Process Model and Notation (BPMN) yaitu suatu metodologi dalam memodelkan proses bisnis dengan tujuan menyediakan notasi yang mudah dipahami oleh semua pengguna bisnis yang terstandardisasi (Object Management Group, 2011).

Terdapat empat kategori dasar yang ada pada BPMN modelling antara lain:

1. Flow Objects terdiri dari event, activities, dan gateway.

2. Connecting Objects biasa digunakan untuk menghubungkan flow object melalui beberapa jenis arrows.

3. Swimlanes terdiri dari pool dan lane. 


\section{Artifacts}

Dapat dimasukkan kedalam model dimana model tersebut dianggap sesuai dalam rangka untuk menampilkan informasi lebih lanjut terkait seperti data yang diproses atau komentar-komentar lain.

\section{B. METODE PENELITIAN}

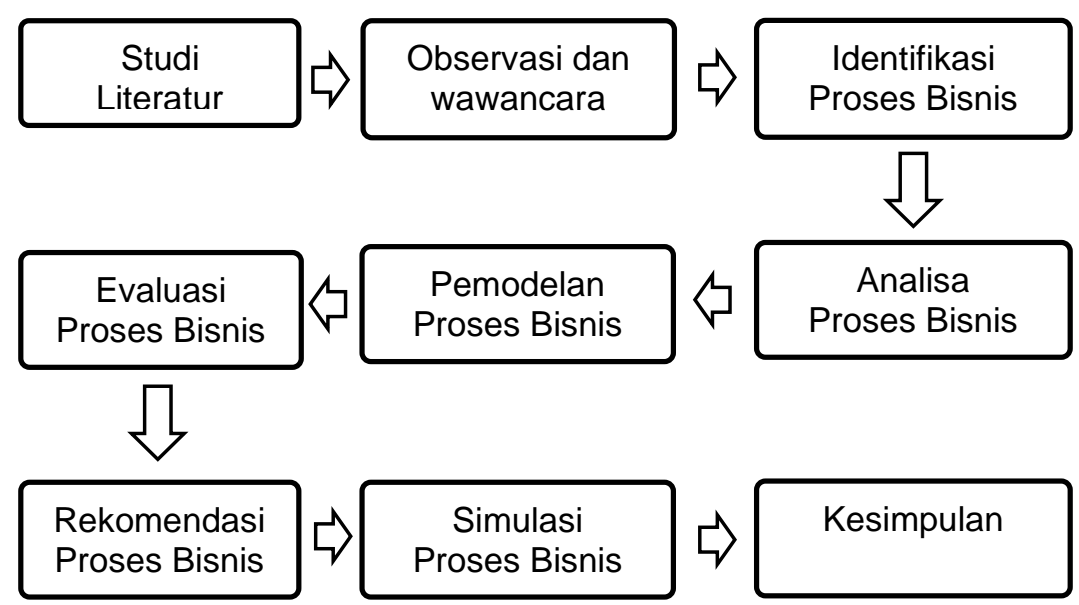

Gambar. 3 Metodologi Penelitian

Pada bab ini akan menjelaskan tentang langkah-langkah atau metode yang digunakan dalam menjalankan penelitian ini. Dimulai dari tahap pertama yaitu studi literatur, observasi dan wawancara, mengidentifikasi dan menganalisis proses bisnis utama dan pendukung, pemodelan, evaluasi, simulasi, dan rekomendasi proses bisnis serta rekomendasi kesimpulan.

Pemodelan dengan menggunakan BPMN untuk memvisualisasikan proses bisnis dengan Bizagi Modeler. Bizagi BPMN Process Modeler adalah aplikasi freeware untuk grafis diagram, dokumen dan mensimulasikan proses dalam format standar yang dikenal sebagai Business Process Modeling Notation/BPMN (www.bizagi.com).

\section{HASIL DAN PEMBAHASAN}

\section{Pemodelan Proses Bisnis Saat Ini}

\section{Identifkasi Proses Bisnis dan permasalahan}

Implementasi pertama dari BPI yaitu organizing for improvement dilakukan pada tahap ini. Dalam identifikasi organisasi dijelaskan tentang informasi organisasi yang dapat mendukung proses pemodelan dan perbaikan proses bisnis. Dengan menjabarkan unsur struktur organisasi, lingkungan organisasi, dan sejarah organisasi.

\section{Analisis Value Chain}

\begin{tabular}{|c|c|c|c|c|}
\hline $\begin{array}{l}\text { Infrastruktur } \\
\text { TPS, Gerobak } \\
\text { sampah }\end{array}$ & $\begin{array}{l}\text { Truk } \\
\text { Pengangkut } \\
\text { sampah }\end{array}$ & $\begin{array}{l}\text { Infrastruktur } \\
\text { TPA }\end{array}$ & & \\
\hline Petugas di TPS & Sopir Truk & $\begin{array}{l}\text { Petugas di } \\
\text { TPA }\end{array}$ & & \\
\hline $\begin{array}{l}\text { Pengadaan } \\
\text { gerobak dan alat } \\
\text { kebersihan }\end{array}$ & $\begin{array}{l}\text { Pengadaan } \\
\text { Truk }\end{array}$ & $\begin{array}{l}\text { Alat } \\
\text { Pengolahan } \\
\text { sampah }\end{array}$ & & \\
\hline Inbond & Operations & Outbound & $\begin{array}{l}\text { Marketing } \\
\text { and Sales }\end{array}$ & Service \\
\hline $\begin{array}{l}\text { Penerimaaan } \\
\text { sampah di } \\
\text { TPS }\end{array}$ & $\begin{array}{l}\text { Operasional } \\
\text { Kendaraan } \\
\text { Pengangkut }\end{array}$ & $\begin{array}{l}\text { Pengiriman } \\
\text { sampah ke } \\
\text { TPA }\end{array}$ & & \\
\hline
\end{tabular}

Gambar. 4 Analisis Value Chain Logistik Sampah 
Gambar diatas menjelaskan identifikasi value chain analysis pengangkutan sampah Kota Cirebon yang dilakukan oleh Dinas Kebersihan dan Lingkungan Hidup Kota Cirebon.

\section{Inbound}

Didalam proses bisnis pengangkutan sampah berisi tentang alur dari penerimaan sampah di TPS. Petugas TPS menerima sampah dari rumah tangga dan industri kecil yang diangkut dengan gerobak sampah.

2. Operations

Dalam proses ini menjelaskan alur dan sistem kerja kendaraan pengangkutan sampah dari TPS ke TPA.

3. Outbound

Proses menjelaskan alur penerimaan sampah di TPA dari dari Kendaraan pengangkut sampah.

\section{Pemodelan dan Proses Bisnis}

Pada tahap ini akan dilakukan pemodelan dan pendefinisian proses bisnis yang berjalan saat ini (As Is) dengan menggunakan tools Busniess Process Modelling Notation (BPMN) untuk memberikan kemudahan pemahaman notasi dalam memodelkan proses bisnis, tahap ini sesuai dengan fase 2 BPI yaitu understanding the process. Pemodelan proses bisnis yang dilakukan pada penelitian ini pada proses bisnis utama yaitu sistem pengangkutan sampah dari TPS ke TPA.

Tabel.1 Identifikasi Proses Bisnis Logistik Sampah

\begin{tabular}{|l|l|}
\hline \multicolumn{2}{|c|}{ Sistem Pengangkutan Sampah sampai ke TPA } \\
\hline Pelaku & $\begin{array}{l}\text { Petugas Gerobak, Petugas TPS, Sopir Truk, Petugas } \\
\text { TPA }\end{array}$ \\
\hline Keterangan & $\begin{array}{l}\text { Proses bisnis ini menjelaskan tentang kegiatan } \\
\text { pengangkutan sampah sampai dengan TPA }\end{array}$ \\
\hline
\end{tabular}

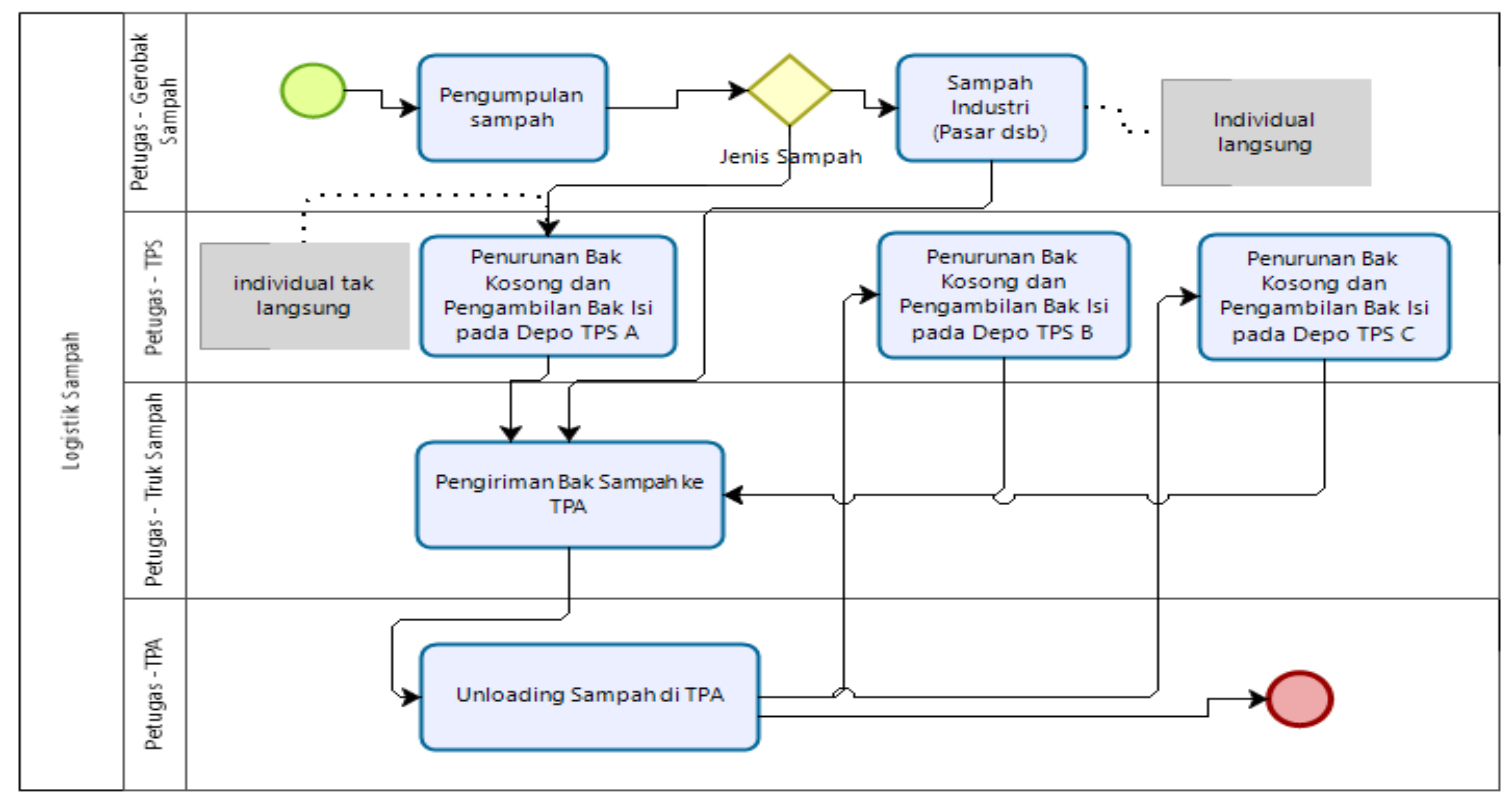

Gambar 5 Proses Bisnis Logistik Sampah $(A s-I s)$

\section{Perbaikan Proses Bisnis}

\section{Evaluasi Proses Bisnis}

Evaluasi proses bisnis dilakukan dengan menggunakan metode Fishbone Diagram dan Five Whys Analysis. Metode Fishbone Diagram dipakai untuk mengidentifikasi semua aspek permasalahan yang mempengaruhi penumpukan sampah di TPS. Metode Five Whys Analysis dilakukan untuk mengidentifikasi akar permasalahan melalui wawancara narasumber. Berdasarkan data permasalaha yang didapat kemudian dielaborasi kembali dengan pertanyaan "mengapa" sebanyak lima kali hingga menemukan sumber permasalahannya. 


\section{Fishbone Diagram}

Berdasarkan indentifikasi permasalahan dengan menggunakan Fishbone Diagram terdapat beberapa permasalah antara lain seperti gambar 5 adalah sebagai berikut:

1. Sistem Operasi

Sistem operasi pengangutan sampah dari TPS ke TPA sudah menggunakan penugasan secara tetap sehingga tidak fleksibel, ditambah lagi dengan tidak berjalannya sistem informasi real time penumpukan sampah di TPS.

2. Sumber Daya Manusia

Petugas kebersihan dan sopir angkutan truk telah bekerja selama puluhan tahun di tempat yang sama sehingga terjadi kejenuhan, ditambah lagi dengan seringnya melakukan kerja lembur melebihi jam kerja yang telah ditentukan.

3. Sarana dan Prasarana

Untuk sarana prasarana terkendala dengan unit kendaraan yang terbatas dan usia kendaraan yang sudah tua sehingga sering terjadi perbaikan yang dapat menggangu jadwal pengambilan sampah.

4. Anggaran Dana

Pengangaran untuk operasional pengangkutan sampah belum maksimal, ditambah lagi sering terjadinya keterlambatan dalam pencairan uang bensin sehingga turk pengangkut sampah tidak dapat beroperasi yang akan menggangu jadwal pengangkutan sampah.

5. Sumber Sampah

Sumber sampah di bagi menjadi dua yaitu sampah rumah tangga dan sampah industri baik melalui TPS atau langsung ke TPA. Secara garis besar volume sampah industri jauh lebih besar dari sampah rumah tangga.

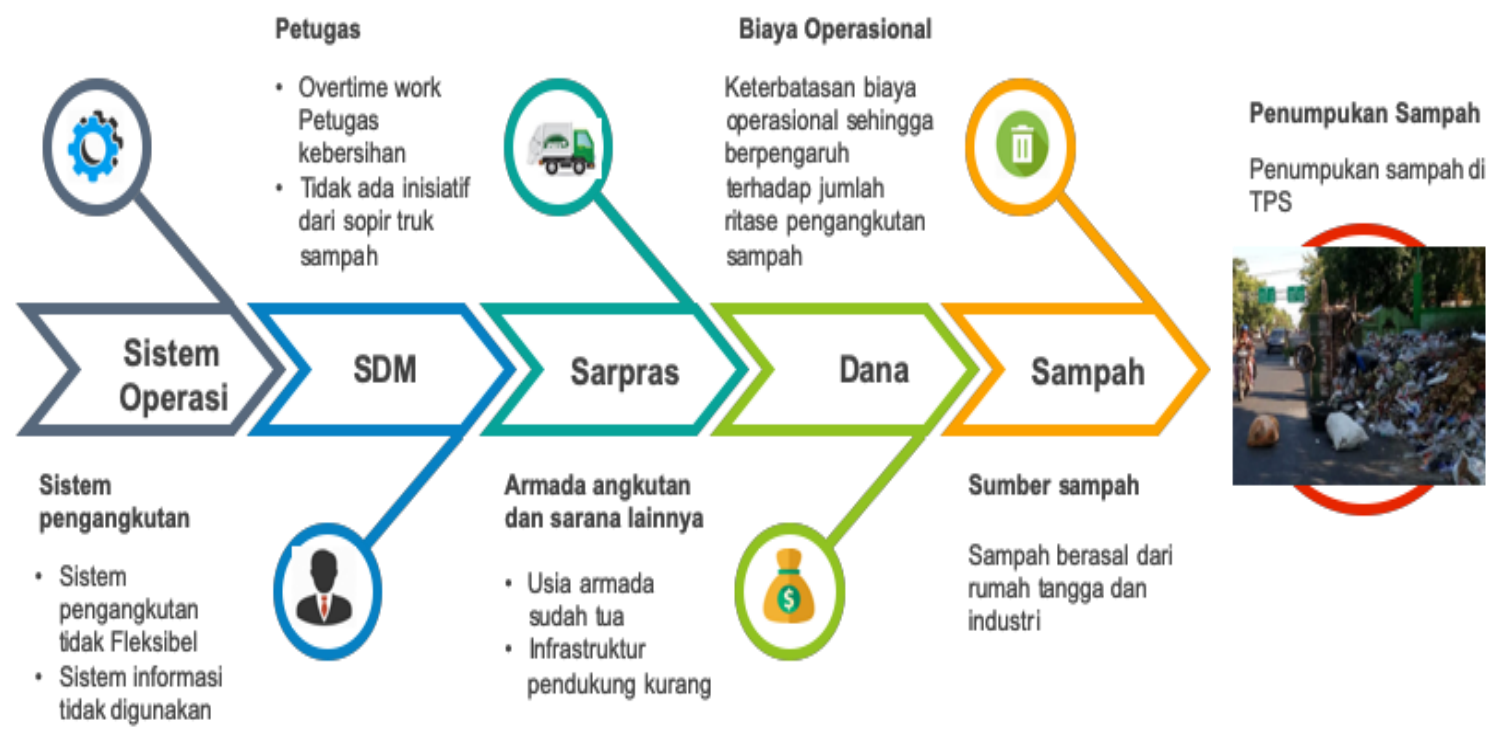

Gambar 5 Fishbone Diagram Pemasalahan Logistik Sampah

\section{Five Whys Analysis}

Dapat dilihat pada Tabel 2, hasil identifikasi menggunakan metode five whys analysis pada proses bisnis logistik sampah menunjukkan akar permasalahan nya adalah pertama dikarenakan tidak di identifikasinya jumlah sampah yang dihasilkan oleh industri dan rumah tangga di Kota Cirebon perharinya. Hal ini tidak dilakukan karean tidak diterapkannya sistem informasi pemantauan sampah di TPS. Selanjutnya sistem penugasan pengangkuan sampah berjalan sesuai dengan yang ditugaskan masing-masing truk pengangkut sampah/jadwal setiap bulan, tidak fleksibel dan tidak terintegrasinya informasi pengangkutan antar truk sampah. Penyebab terakhir sistem tidak dijalankan karena keterbatasan APBD Dinas Lingkungan Hidup Kota Cirebon untuk menjalankan operasional kegiatan Logistik Sampah. 
Tabel 2 Five Whys Analysis Logistik Sampah

\begin{tabular}{|l|l|l|l|l|}
\hline \multicolumn{1}{|c|}{ Masalah } & \multicolumn{1}{|c|}{ Why 1 } & \multicolumn{1}{c|}{ Why 2 } & \multicolumn{1}{c|}{ Why 3 } & \multicolumn{1}{c|}{ Why 4 } \\
\hline $\begin{array}{l}\text { Penumpukan } \\
\text { sampah di TPS }\end{array}$ & $\begin{array}{l}\text { Tidak di } \\
\text { identifikasi } \\
\text { jumlah sampah } \\
\text { yang akan masuk } \\
\text { di TPS }\end{array}$ & $\begin{array}{l}\text { Sistem informasi } \\
\text { pemantauan } \\
\text { sampah di TPS } \\
\text { tidak berjalan }\end{array}$ & $\begin{array}{l}\text { Sistem } \\
\text { pengangkutan } \\
\text { terjadwal sesuai } \\
\text { penugasan dan } \\
\text { tidak fleksibel }\end{array}$ & $\begin{array}{l}\text { Keterbatasan } \\
\text { dana operasional } \\
\text { logistik sampah }\end{array}$ \\
\hline
\end{tabular}

\section{Rancangan Proses Bisnis yang telah diperbaiki}

Rancangan proses bisnis yang telah diperbaiki berdasarkan hasil evaluasi dari proses bisnis sebelumnya. Tahapan perancangan ini adalah mengidentifikasi permasalahan yang ada dalam proses bisnis, dilanjutkan dengan pemilihan tools streamlining yang sesuai dengan permasalahan yang dihadapi.

Tabel. 3 Streamlining Pada Proses Bisnis Logistik Sampah

\begin{tabular}{|c|c|c|}
\hline Masalah pada proses awal & Jenis Streamlining & Proses bisnis rekomendasi \\
\hline $\begin{array}{l}\text { Sistem pengangkutan } \\
\text { terjadwal sesuai penugasan } \\
\text { dan tidak fleksibel }\end{array}$ & $\begin{array}{l}\text { Automation and/or } \\
\text { Mechanization Upgrading } \\
\text { dan Process Cycle-time } \\
\text { Reduction }\end{array}$ & $\begin{array}{l}\text { Sistem operasi pengangkutan } \\
\text { terintegrasi dan fleksible } \\
\text { sehingga memaksimalkan } \\
\text { routing pengangkutan sampah } \\
\text { dari TPS ke TPA }\end{array}$ \\
\hline
\end{tabular}

\section{Rekomendasi pada Proses Bisnis}

Berdasarkan proses bisnis yang ada pada model proses dibawah ini merupakan pemodelan proses bisnis rekomendasi yang telah dilakukakan evaluasi dan rancangan perbaikan proses bisnis.

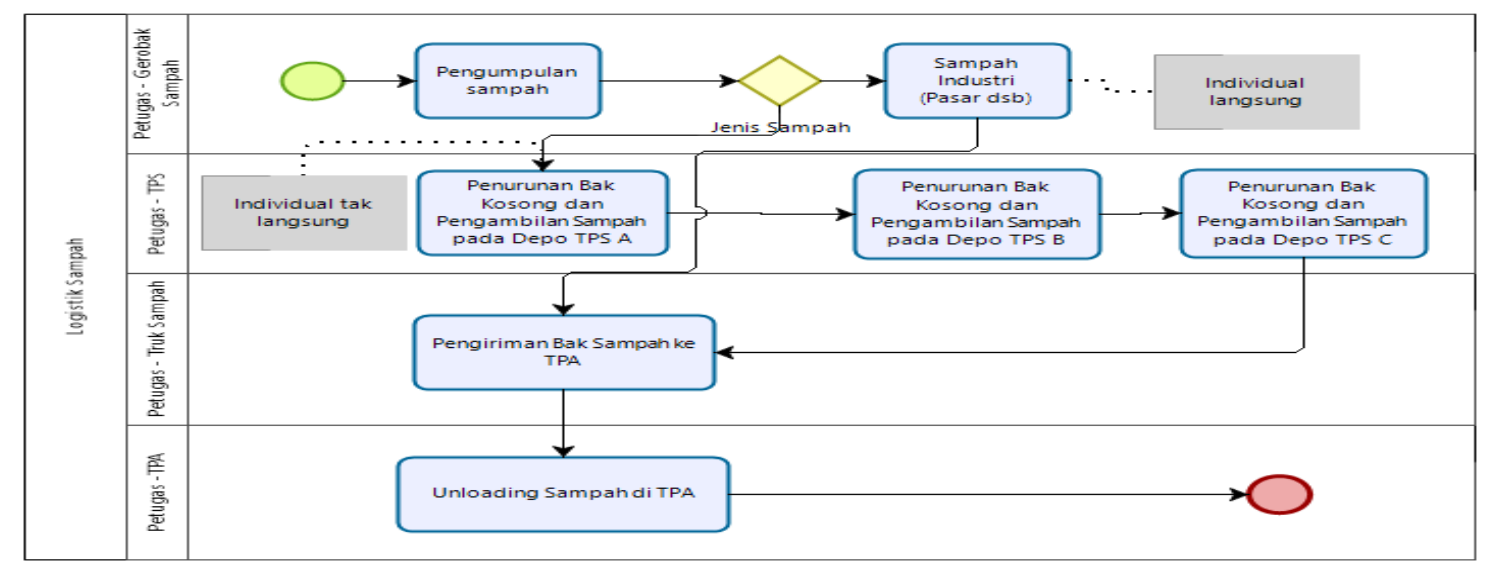

Gambar. 6 Proses Bisnis Logistik Sampah (To-Be)

\section{Simulasi Proses Bisnis}

Simulasi dilakukan sampai pada level resources analysis yang dijalankan pada proses bisnis sebelum dilakukan perbaikan $(A s-I s)$ dan proses bisnis setelah dilakukan perbaikan (To-Be) untuk dapat melihat perbandingan waktu dan penggunaan sumber daya yang dibutuhkan. Perubahan proses bisnis sebelum dilakukan perbaikan ( $A s-I s)$ dan proses bisnis setelah dilakukan perbaikan ( $\mathrm{To}-\mathrm{Be}$ ) adalah dengan penerapan sistem pemantauan TPS secara realtime dan penerapan sistem operasi pengangkutan terintegrasi dan fleksible sehingga memaksimalkan routing pengangkutan sampah dari TPS ke TPA.

\section{Asumsi}

Asusmsi didasarkan dengan pelaksanaan proses logistik sampah yang dilakukan oleh Dinas Lingkungan Hidup Kota Cirebon menurut pengamatan, adalah sebagai berikut:

1. Durasi waktu selama 30 hari;

2. Dalam 1 hari melakukan perjalanan 1-3 rit pengangkutan sampah dari TPS ke TPA;

3. Semua pelaku yang terkait hadir dalam proses tersebut;

4. Wawancara dan observasi menjadi dasar pennetuan waktu dalam setiap aktivitas. 


\section{Simulasi Pengangkutan Logistik Sampah dari TPS ke TPA (As-Is)}

Tabel. 4 Simulasi Time Analysis Logistik Sampah (As-Is)

\begin{tabular}{|l|c|}
\hline Minimal Time & 11 Jam \\
\hline Maximal Time & 29 hari 7 Jam \\
\hline Average Time & 14 hari 9 Jam \\
\hline
\end{tabular}

Hasil simulasi time analysis pada tabel diatas adalah dalam waktu 1 bulan dengan perhari dilakukan 1-3 rit pengangkutan sampah dari TPS ke TPA dapat terselesaikan dalam waktu minimum 11 jam, waktu maksimum 29 hari 7 Jam dan rata-rata 14 hari 9 Jam.

Tabel. 5 Simulasi Resource Analysis Logistik Sampah (As-Is)

\begin{tabular}{|l|c|}
\hline \multicolumn{1}{|c|}{ Resource } & Utilzation \\
\hline Petugas Gerobak - Penerimaan sampah di TPS & $100 \%$ \\
\hline Petugas TPS - Loading sampah pada Truk sampah & $99,20 \%$ \\
\hline Sopir Truk - Pengangkutan sampah dari TPS ke TPA & $55,17 \%$ \\
\hline Petugas TPA - Unloading sampah di TPA & $98,82 \%$ \\
\hline
\end{tabular}

Hasil pemanfaatan sumber daya pada proses bisnis logistik sampah saat ini terlihat pada tabel diatas.

\section{Simulasi Proses Bisnis Pengangkutan Logistik Sampah dari TPS ke TPA (To-Be)}

Tabel. 6 Simulasi Time Analysis Logistik Sampah (To-Be)

\begin{tabular}{|l|c|}
\hline Minimal Time & 17 Jam \\
\hline Maximal Time & 29 Hari 7,5 Jam \\
\hline Average Time & 15 Hari 4 Jam \\
\hline
\end{tabular}

Hasil simulasi time analysis ditunjukan tabel diatas, dalam waktu 1 bulan dengan perhari dilakukan 1-3 rit pengangkutan sampah dari TPS ke TPA dapat diselesaikan dengan waktu minimum 11 jam, waktu maksimum 29 hari 7,5 jam dan dengan rata-rata 15 hari 4 jam.

Tabel 7 Simulasi Resource Analysis Logistik Sampah (To-Be)

\begin{tabular}{|l|c|}
\hline \multicolumn{1}{|c|}{ Resource } & Utilzation \\
\hline Petugas Gerobak - Penerimaan sampah di TPS & $100 \%$ \\
\hline Petugas TPS - Loading sampah pada Truk sampah & $98,10 \%$ \\
\hline Sopir Truk - Pengangkutan sampah dari TPS ke TPA & $89,48 \%$ \\
\hline Petugas TPA - Unloading sampah di TPA & $57,22 \%$ \\
\hline
\end{tabular}

Dari Tabel 7 terlihat hasil pemanfaatan sumber daya pada proses bisnis logistik sampah rekomendasi.

Berdasarkan hasil dari perbandingan hasil diatas dapat disimpulkan dengan adanya perbaikan proses bisnis $A s-I s$ ke To-Be dapat meningkatkan pemanfaatan sumber daya pada proses binis logistik sampah khususnya pengangkutan sampah dari TPS ke TPA sebesar 34,31\% (89,48\%-55,17\%) sehingga dapat mengurangi penumpukan sampah di TPS. Untuk waktu pengangkutan sampah dari sumber ke TPA mengalami kenaikan dengan adanya peningkatan sumber daya, salah satu solusinya adalah dengan penambahan armada kendaraan truk pengangkut sampah.

\section{KESIMPULAN}

Berdasarkan hasil penelitian yang telah dilakukan pada Dinas Lingkungan Hidup Kota Cirebon, maka dapat diperoleh kesimpulan sebagai berikut:

1. Berdasarkan analisis value chain analysis pada Dinas Lingkungan Hidup Kota Cirebon terdapat proses bisnis utama dan proses bisnis pendukung. Proses bisnis utama adalah logistik sampah dari sumber sampai dengan TPA.

2. Pada proses logistik sampah terdapat beberapa aktivitas yang dapat dilakukan streamlining, melalui teknik process cycle-time reduction yang bertujuan agar sistem operasi pengangkutan terlaksana secara terintegrasi dan fleksible untuk semua truk pengangkut sampah sehingga dapat memaksimalkan routing pengangkutan sampah dari TPS ke TPA.

3. Hasil perbandingan simulasi proses bisnis awal dan proses bisnis rekomendasi menunjukan bahwa disimpulkan dengan adanya perbaikan proses bisnis dapat meningkatkan pemanfaatan sumber daya pada proses binis logistik sampah khususnya pengangkutan sampah dari TPS ke TPA sehingga dapat mengurangi penumpukan sampah di TPS. 
4. Dengan adanya kenaikan keaikan waktu operasional pengangkutan sampah yang disebabkan peningkatan sumber daya, salah satu solusinya adalah dengan penambahan armada kendaraan truk pengangkut sampah.

\section{DAFTAR PUSTAKA}

[1]. Abreu, J., 2013. Business Processes Improvement on Maintenance Management: a Case Study. Universidade do Algarve Portugal.

[2]. Andiç, E., Yurt, O. and Baltacioğlu, T., Green Supply Chains: Efforts and Potential Applications for The Turkish Market, Resources, Conservation and Recycling, 58,

[3]. 2012, pp. 50- 68. Anwar, SN. (2011). Manajemen Rantai Pasokan (Supply Chain Management) Konsep dan Hakikat.Jurnal Dinamika Informatika, Vol 3 No 2. [e-jurnal]. doi: http://www.unisbank.ac.id/ojs/index.php/fti2/a rticle/view/1315/531

[4]. Bizagi, 2018. Simulation in Bizagi. [online] Tersedia di: < http://help.bizagi.com/processmodeler/en/index.html?simulation_in_bizagi.htm> [Diakses pada 11 November 2019]

[5]. Chen, C. C., Shih, H. S., Shyur, H. J. and Wu, K. S., A Business Strategy Selection of Green Supply Chain Management via Analytic Network Process, Computers and Mathematics with Applications, 64, 2012, pp. 2544-2557.

[6]. Chopra, S. dan Meindl, P. 2004. Supply Chain Management: Strategy, Planning and Operations, 2nd Edition. Upper Saddle River, NY: Prentice-Hall

[7]. Eltayeb, T. K., Zailani, S. and Ramayah, T., Green supply chain initiatives among certified companies in Malaysia and environmental sustainability: Investigating the outcomes, Resources, Conservation and Recycling, 55, 2011, pp. 495-506.

[8]. Huang, X., Tan, B. L. and Ding, X., Green Supply Chain Management Practices: A Sectoral Investigation Into Manufacturing SMEs in China, 2012 International Conference on Economics, Business and Marketing Management, 29, 2012, pp. 147-151.

[9]. Kusuma, I., 2015. Perbaikan Proses Bisnis Penyusunan Rencana Kerja Dinas Pemuda Olahraga dan Pariwisata Kabupaten Bandung Menggunakan Metode Business Process Improvement Untuk Memenuhi Peraturan Menteri Dalam Negeri No. 54 Tahun 2010 dan Klausul 7.3 ISO 9001:2008. S1. Universitas Telkom Bandung.

[10].Lee, S. M., Kim, S. T. and Choi, D., Green Supply Chain Management and Organizational Performance, Industrial Management \& Data Systems, 112(8), 2012, pp. 1148-1180.Harrington, H.J., 1991. Business Process Improvement. New York: McGraw-Hill, Inc.

[11].Murnawan, Heri., Mustofa. 2014. Perencanaan Produktivitas Kerja Dari HasilEvaluasi Produktivitas Dengan Metode Fishbone Di Perusahaan Percetakan Kemasan Pt.X. Jurnal Teknik Industri HEURISTIC Vol 11 No 1 April 2014. Prodi Teknik Industri FT Universitas 17 Agustus 1945 Surabaya.

[12].Object Management Group, 2011. Business Process Model and Notation (BPMN). [pdf] Tersedia di <http://www.omg.org/spec/BPMN/2.0/PDF> [Diakses pada 11 November 2019]

[13].Perdana T, Nurhayati, Kusnandar. (2013). Improvement Model of Supply Chain Management and Agribusiness Cluster of Red Chili: an Experience in West Java. The Article was presented in International Workshop of Agri Supply Chain Management on July 1st, 2013 at Hotel Mer- cure Surabaya, Indonesia. In Collaboration Between University of Jember and University Putra Malaysia.

[14].Pratama, I., Pramono, D., Setiawan, Yudi., 2018. Perbaikan Proses Bisnis Menggunakan Metode Business Process Improvement (BPI) (Studi Kasus Pada Bagian Pelaksana Urusan Logistik UTD Palang Merah Indonesia (PMI) Kota Malang). Jurnal Pengembangan Teknologi Informasi dan Ilmu Komputer.

[15].Pojasek, Robert B, 2000. Enviromental Quality Management. ABI/INFORM Trade \& Industry.

[16].Porter, M., 1998. Competitive Advantage: Creating and Sustaining Superior Performance. New York: The Free Press.

[17].Serrat, O., 2009. The Five Whys Technique. s.l.:Knowledge Slutions.

[18].Undang Undang Nomor 18 tahun 2008 tentang Pengelolaan Sampah.

[19].Weske, M., 2012. Business Process Management, Second Edition. London: Springer.

[20].Zhu, Q., Sarkis, J. and Geng, Y., Green Supply Chain Management in China: Pressures, Practices and Performance, International Journal of Operations \& Production Management, 25(5), 2005, pp. 449-468.

[21].Zhu, Q., Sarkis, J. and Lai, K., Green Supply Chain Management Implications for Closing The Loop"e, Transportation Research Part E, 44, 2008, pp. 1-18. 